\title{
Workfare in the Undemocratic States: The Case of China
}

\section{Introduction}

Workfare is a key welfare approach in many Western countries. Some Chinese academics and mass media assert that Western-style workfare should be further implemented in China; portraying public assistance recipients as lazy and abusing of public benefits without incentive for work (Xinhua Net, 2006; People's Daily Net, 2007). A senior official proposed that able-bodied claimants should only receive short-term financial assistance, with a requirement of doing community work (Qiu, 2005).On the other hand, it was reported that the levels of financial assistance for poor people are relatively low (Zhang and Tang, 2005). Therefore, the thesis of China's attractive benefits leading to welfare dependency needs to be supported by more convincing evidence.

Workfare seems to be the Chinese government's strategy to manage welfare demands from both laid-off workers and other poor people. As a result of the restructuring of a large number of state-owned enterprises (SOEs), both central and local governments had limited resources to pay compensation for laid off workers. It was found that 24,214 SOEs failed to pay wages and pensions to 3.5 million workers in 1996 (Chen, 2000). Also in 1997, nearly one third of laid-off workers from small SOEs and about $8 \%$ from large SOEs did not receive unemployment assistance (Cai, 2002). Despite the mentioned welfare pressures from laid-off workers, the Chinese government introduced new social assistance benefits for poor people in 
urban and rural areas in 1997 and 2007 respectively because of having to secure social stability (Chan 2011). Thus, coercive measures associated with workfare policy help control the number of social security applicants, reducing the Chinese government's financial pressures.

Western-style workfare has been implemented in democratic countries in which social security policies are monitored by public representatives and the power of welfare bureaucrats is checked by an independent judicial system. China, however, is an authoritarian polity where the general public has little power in shaping workfare policies and monitoring the activities of welfare officials. Therefore, this paper examines the problems caused by workfare in China and is comprised of three sections. Section one examines welfare bureaucrats and welfare appeals in some Western democratic welfare states; section two investigates the problems of workfare in China; and, section three, based on China's experiences, discusses the implications of workfare in authoritarian states.

\section{Social Services and Welfare Bureaucrats}

Workfare has become a key approach in some Western welfare states and the concept of activation is a 'cornerstone of social policy development' (Lodemel and Trickey, 2000: 14). The key feature of workfare is mandatory participation that requires unemployed recipients to regularly meet welfare officers, attend education and employment programmes and, in some cases, complete unpaid community work. Some government leadership believe that 
compulsory training and other measures can benefit welfare recipients by enhancing poor people's employability and ultimately tackling the underlying cause of poverty.

On the other hand, workfare has aroused discussions about the power of frontline welfare bureaucrats. Lipsky (1980) pointed out that street-level bureaucrats, who directly provide services for welfare users, do not have adequate resources to achieve the original policy objectives. Facing unmanageable demands, welfare bureaucrats in the USA used various strategies to cope with their duties such as limiting the information of services, increasing the waiting time and imposing extra restrictions on eligibility. For example, Ellis (2007: 416) found that British social workers in a local authority tried to avoid proposing direct payments arrangements to service users because of 'deficiencies in the administrative infrastructure' and the 'lack of support for recipients'. These problems were confirmed by a study which found that there was no 'unclear guidance' and also 'a marked lack of adequate and detailed information' for service users on using direct payments (The Princess Royal Trust for Carers, 2009: 3). Some social care professionals did not attempt to promote direct payments 'for fear of raising expectations which were unlikely to be fulfilled' as a result to limited funds (The Princess Royal Trust for Carers, 2009: 3).

Limited resources also restricted the effectiveness of Australia's One to One programme, which aimed to offer individualised support and services to unemployed recipients. According to Howard (2012), too many cases were assigned to welfare workers of the Centrelink that administrates the programme. The workers rationed interactions with service 
users by offering them with 'very few, very short appointments' (Howard, 2012: 665). As a result, service users experience a programme that has the appearance of functioning but ultimately lacks depth of social support and opportunity for real change. It was reported that some welfare workers even portrayed negative images of welfare claimants in order to rationalise their social control role. After interviewing 100 welfare-to-work program managers in North Carolina in the United States of America, Seale and her colleagues (Seale et al, 2012: 509) reported that some felt their clients lacked motivation; some believed they were responsible for 'program failures' because of being 'unmotivated', 'childlike' and 'incompetent'. By portraying the negative images of social security recipients, the programme managers could justify their disciplining and policing role (Seale et al, 2012).

The illustrated evidence shows that welfare officers have developed strategies to manage workloads and justify their control over clients' behaviour. Therefore, the rights of poor people can be suppressed by street-level bureaucrats' coping strategies in addition to a government's complicated benefit rules. This is further complicated by the fact that impoverished services users tend to be less educated and know little about official policies often they are left feeling both confused and intimidated by the benefits claims process.

\section{Welfare Appeals in Democratic Countries}

Western democratic countries use welfare appeals and complaints mechanisms to check the power of welfare bureaucrats. As noted by Reich (1965: 1256-57), 'In a society that is highly 
organized, institutional and bureaucratic, law is the essential means by which individuals are protected; law alone can ensure the fairness and lack of oppression that is essential to individual independence'. In the UK, if welfare recipients are not satisfied with a Jobcentre Plus' explanations on terminating their benefits, as per legal rights service users can make appeals to the Social Security and Child Support Tribunal (Directgov, 2012), which is the first-tier tribunal. Organisations such as the Citizens Advice Bureau, local welfare rights groups, trade unions and law centres not only offer free or low-cost advice to appellants; they can also accompany them to oral hearings. If the outcome is unsatisfactory, there are mechanisms for further appeals to an Upper Tribunal.

Similarly, welfare recipients in Australia can lodge complaints to the Social Security Appeals Tribunal, which is an independent statutory agency providing 'a mechanism of review that is fair, just, economical, informal and quick' (Centrelink, 2012: n.p.). The recipients can make further appeals to the Administrative Appeals Tribunal and the Court system. In the US, welfare recipients can bring their cases to a federal district court or a state court. Alternatively, more frequently they choose an administrative fair hearing conducted by a state hearing examiner (Geetter, 1988).

It should be stressed that Western democratic welfare states are not homogeneous but have some degree of variation. According to Esping-Andersen (1990), Western welfare states can be divided into three types of regimes, including a liberal regime, a conservative regime and a social democratic regime. The level of public assistance and its application requirements as 
well as the welfare role of an individual, the family and state vary among Western welfare states. Also, like undemocratic countries, the welfare appeal systems in Western democratic states have deficiencies. For example, the welfare appeal system in Ireland was criticised by the Free Advice Centres (2012) as lacking transparency and consistency as well as causing lengthy delays in decisions.

In the USA, legal barriers and the biases of administrative law judges have suppressed the rights of welfare appellants (Geetter, 1988; Lens, 2007). For example, its fair hearing mechanism has disadvantaged poor people because they are unable to recover fees even after winning their claims (Geetter, 1988). Lens's (2007: 329) study found that at some fair hearings welfare recipients 'do not have the power to command the proof they need. They are often outmatched by their opponents'. Such hearings were transformed into interrogations of the appellants. The credibility of administrative law judges is also under scrutiny. After analysing the results of some research studies, Golin (1995: 1544) concluded that there was 'convincing evidence of gender and racial bias' in some benefits hearings conducted by administrative law judges. Vendel (2005: 770) also reported similar findings, stressing that 'bias inevitably seeps into' the decisions of administrative law judges from 'racial, gender, class prejudice, to bias against disability claimants in general'. According the Sargent Shriver National Center on Poverty Law (2014: n.p.), the benefits of many disability claimants in Queens, New York, were denied by administrative law judges 'in a pattern of repeated, glaring, and often intentional legal errors'. 
Despite the mentioned weaknesses, the importance and achievements of welfare appeals mechanisms in Western democratic states should not be underestimated. Fair hearings, for example, are 'central to welfare rights strategies' in the US because they help change social policy from below (Kornbluh, 1998: n.p.). Lens (2011) reported that fair hearings offered opportunities to welfare claimants to address their social and materials injuries, recast their relationship with government officials, and restore their self-respect and dignity. Lens (2011: 437) concluded that the hearings provided 'a breeding ground for germinating grievances among those citizens who have chosen voice over exit within the welfare system'. In the UK, welfare appeals have effectively safeguarded the rights of poor citizens by overturning a significant number of official decisions. Among 276,400 hearing clearances at the Social Security and Child Support Tribunal in 2009-10, 35\% of decisions were in favour of the appellants (Ministry of Justice, 2011).

In summary, the power of welfare bureaucrats has been enhanced by workfare as they can shape unemployed recipients' job-seeking behaviour, reducing and even terminating their benefits. Also, welfare bureaucrats always use various strategies to manage workloads; limiting welfare recipients' access to social services and other obstructionist tactics is a known problem. In Reich's (1965: 1246) words, welfare provision is surrounded by the processes of administrative procedure that 'has developed its own abuses and oppressiveness'. To balance the power between government officials and social security recipients, some Western democratic countries have established welfare appeals systems. Fair hearings in the U.S have embodied 'foundational notions of due process and the rights of citizens to 
challenge arbitrary government power' (Lens, 2011: 434). On the other hand, China is an authoritarian polity; this raises questions as to whether China has the necessary arrangements to safeguard the rights of poor citizens when it has been urged to adopt more Western-style workfare measures.

\section{Workfare and China's Social Security Administration}

In China, workfare is a decentralised and loose social policy (Chan, 2011). It is hard to gather all workfare programmes in different parts of China since each region has set up their own unique schemes. This development was mainly caused by central government's simple guideline by only starting that beneficiaries of the Minimum Living Standard Scheme (MLSS) with a work capacity have to join community work organized by residents' committees (ROs) (State Council, 1999). As a consequence, numerous workfare programmes have been launched as China has more than 160 cities with more than 2 million residents (The Telegraph, 2013). It should be noted that the details of some local workfare programmes cannot be easily accessed as the published information varies from local government to local government. Against this background, this paper will focus on workfare in Guangzhou because it was the first Chinese city that introduced a comprehensive workfare scheme in 2005. In addition, more empirical research studies were conducted in Guangzhou which can provide essential data for assessing the impact of workfare. Apart from Guangzhou, this paper also will examine some common national policies that affect both Guangzhou and other regions such as the role of street offices (SOs), residents' committees (RCs), and 
villagers' committees (VCs) in implementing workfare as well as the effectiveness of the existing welfare appeals mechanism.

In Guangzhou, workfare mainly targets the recipients of MLSS. There are two types of minimum living standard schemes: one is for urban citizens, called the Urban Minimum Living Standard Scheme and another is for farmers, called the Rural Minimal Living Standard Scheme. The urban scheme was set up in 1997 (State Council, 1997) and its details were spelt out in The Urban Residents' Minimal Living Standard Scheme Ordinance (State Council, 1999). The ordinance defines basic necessities as clothing, food and housing; it also urges local authorities to take expenses such as water, electricity, gas, and education for children and young people into account while developing their local schemes. From 2000 to 2009, the number of the Urban Minimum Living Standard Scheme recipients increased six fold, from 4 million to 23.5 million, and the average benefit level increased from $¥ 149$ in 2003 to $¥ 228$ in 2009 (Ministry of Civil Affairs, 2010). The Rural Minimal Living Standard Scheme was established nationally following the publication of The Notification on the Establishment of a Nationwide Minimal Living Standard Scheme in Rural Area in July 2007. Poor families can apply for public assistance if their household income is below the threshold of the regional MLSS (Ministry of Civil Affairs, 2008). From 2001 to 2009, the number of Urban Minimum Living Standard Scheme claimants dramatically increased by more than 10 times, from 3 million to 47.6 million (Ministry of Civil Affairs, 2010). A family is eligible for the MLSS if the average income of its family members is below a region's poverty threshold. In Guangzhou, this is a monthly income of $¥ 530$ for urban residents and $¥ 467$ for rural 
residents in 2013(Southern Metropolis Daily, 2013).

The Guangzhou government published its workfare policy in The Regulations for MLSS Recipients in Guangzhou City to Participate in Community Work in 2005(Guangzhou Municipal Civil Affairs Bureau, 2005). The document listed out the following key elements:

(a) Target claimants: Unemployed women from 18 to 50 years old and unemployed men between 18 and 60 are required to do community work three-and-a-half days weekly with a total of 11 hours and 30 minutes per week (Golden Goat Net, 2005).

(b) Type of community work: A wide range of community work is offered to claimant, including community sanitation, neighbourhood patrols, providing support for older people, and arranging and distributing donated goods.

(c) Sanctions: If welfare claimants fail to do community work twice a month (Golden Goat Net, 2005) or their able-bodied members refuse to accept job offers twice, their benefits will be ceased (Shishu Street Office, 2008).

According to the Guangzhou municipal government, the workfare policy aimed to enhance a sense of reciprocity among public assistance recipients (Golden Goat Net, 2005).

In Guangzhou, SOs and RCs are appointed to administrate the community work programme (Guangzhou Municipal Civil Affairs Bureau, 2005; Xian Street Office, 2013). The following section will analyse problems associated with workfare in China based on the experiences of 
Guangzhou, supported by evidence in other regions.

\section{Voluntary organisations and the MLSS}

In China, volunteers from community organisations act as frontline social security officers to handle MLSS applications. Local authorities asked residents' committees and villagers' committees to take up key welfare duties, including offering advice to applicants, assisting them in completing forms, checking eligibility, giving recommendations to higher administrative bodies for benefit approvals and carrying out home visits. Although the Chinese government claims that RCs are self-governing neighbourhood organisations (Ministry of Civil Affairs, 2008), lower level government agencies often treat them as subordinate administrative units, asking them to fulfil many official duties (Ministry of Civil Affairs, 2008). It was reported that RCs had to deal with 48 main tasks and 168 minor tasks. As a consequence, their officers did not have sufficient time to attend meetings and tackle community problems (Ministry of Civil Affairs, 2008). In short, the RCs are actually local governments' foot soldiers for launching social, economic and political activities.

In rural areas, VCs are taking on a role similar to RCs in cities. In 2007, there were 613,000 VCs through which poor families could submit their MLSS applications (Ministry of Civil Affairs, 2008). The VCs will firstly assess the financial conditions of the public assistance applicants and then send their recommendations to the township government. After rechecking the applicants' details, officials from the township government will pass their 
comments to the county government for final approval. The VCs also conduct regular income checks and even home visits on the existing claimants (Ministry of Civil Affairs, 2008).

Obviously, both RCs and VCs are performing social security duties that should be undertaken by civil servants in Western democratic countries. Ngok's ${ }^{1}$ (2012) study in Guangzhou reported that the duties of RCs include checking the MLSS applications, holding meetings to discuss eligibility, paying benefits to successful applicants, arranging community work for recipients, checking the financial conditions of the existing recipients and managing the MLSS records. By using non-government organisations to implement public assistance, the Chinese government can quickly mobilise 300,000-500,000 volunteers to handle MLSS applications in urban areas (Tang, 2005). In this way, local authorities do not need to set up new social security offices, nor recruit additional welfare staff to deal with welfare expansion following China's economic reform.

However, there are two problems associated with this arrangement. Firstly, the added duties have overburdened the community organisations; there is a serious doubt about their capacities to provide an acceptable quality of service to claimants (Tang, 2005). Secondly, it is questionable whether the volunteers have the required knowledge and skills to enforce coercive measures without threatening recipients' welfare rights. According to the central government, among those who ran the services of RCs, $70 \%$ were older people and $80 \%$ only had primary and secondary education (Ministry of Civil Affairs, 2008). Other studies also reported that the volunteers lacked professional qualifications and the quality of their services 
was inconsistent (Tang, 2002; Qingdao Public Administration Institute Research Team, 2003; $\mathrm{Wu}$ and Shi, 2005). As mentioned earlier, the Guangzhou municipal government asked the workers of RCs to implement workfare activities. However, some of them were found to be unable to communicate effectively with clients. In response to complaints about the poor communication skills of RC's workers, a government official admitted, 'Because the workers of RCs are from different social backgrounds and also have to bear a lot of duties, it is common to see some of them have poor work attitudes' (Ngok, 2012).Because of frontline workers' poor training, some unemployed workers cannot get essential benefit information, nor can their psychological and employment needs be accurately assessed. For example, without having received additional support, a single mother in Guangzhou was asked to take up a job preventing her from taking care of her daughter and mother-in-law. She pointed out, 'Yes, I said I have reasons for not taking up their offer but they just refused to listen and only said that my benefit will be terminated if I don't accept the job' (Ngok et al, 2011). Obviously, welfare workers 'failed to consider job offers on a case-by-case basis by taking the beneficiaries' individual abilities into consideration' (Ngok et al, 2011).

\section{The problems of official social security administration}

In China, SOs are the lowest official administrative units, launching social security and other public services such as health, housing, education, birth control and crime prevention. In Guangzhou, poor people can submit their MLSS applications to either SOs or RCs and then their staff will check the information and carry out home visits. The SOs will also put the 
names of applicants on the public notice boards in order to get comments from applicants' neighbours. Before sending to the district government, a SO will comprehensively assess applicants' family conditions with the help of the members of RCs and workers from the community assistance point (Huanghuagang Street Community Service Centre, 2013).Some SOs in Guangzhou have set up Comprehensive Assistance Centres to handle various types of social security benefits. For example, the Yuexiu district government established Comprehensive Assistance Centres in its 22 SOs and their workers will assess all MLSS applications (Xin Hua Net, 2007).

Lacking professional training among frontline welfare bureaucrats is one of the weaknesses of China's social security system. Although the Ministry of Civil Affairs (2008: 68) admitted that workers dealing with the MLSS applications require 'professional values, knowledge and skills', most welfare officers do not possess social work, counselling, or career guidance qualifications. Lipsky (1980) stated that street-level bureaucrats do not disclose information in order to minimise workloads. An example of this is unemployed claimants in Guangzhou were reportedly given little information about working hours for community work and financial incentives for keeping their jobs (Ngok, 2012).

As mentioned previously, SOs and RCs in Guangzhou are responsible for arranging community work. They can define the contents and requirements of community work and also monitor the MLSS recipients' attendance (Guangzhou Municipal Civil Affairs Bureau, 2005). However, the community work programmes are mainly social and community services 
for older and disabled people (Guangzhou Municipal Civil Affairs Bureau, 2005), which are not tailor-made programmes for addressing welfare recipients' employment barriers. Also, it was reported that the participants were asked to do voluntary work regardless of their health conditions. For example, a claimant in Guangzhou was forced to do community work despite ill health (Ngok, 2012). Another study reported that an acute cancer patient was asked to continue doing a patrol duty in the evenings because the authority could not find someone to swap with him. As the respondent stated, 'I am scared of negotiating with the RC's workers because of worrying about benefit cuts' (Wong and Li, 2013). Obviously, by enforcing coercive welfare measures, volunteers and untrained welfare workers have put the physical health of some welfare recipients at risk.

Similar problems were reported in other regions. For example, a recipient was frustrated with having been asked to repair public roads, which was actually a village authority's routine duty (People's Daily Net, 2012). One local government required old age recipients to perform community work, and their adult children were even allowed to do it on their behalf. Another local government allowed the MLSS recipients to pay someone to do community work (Yunnan Net, 2012). These practices clearly showed that community work in some regions is a punishment on poor people with the main purposes of maintaining work ethics, family dependency and enhancing the stigmatisation of public assistance. The illustrated examples also indicate that there are no proper guidelines on the contents and objectives of community work. As a result, some government officials have abused their power, forcing welfare claimants to perform tasks without considering their physical limitations and employment 
needs.

Many welfare bureaucrats, similar to the program managers in the US discussed earlier (Seale et al, 2012), also hold a negative attitude towards welfare beneficiaries. Some regarded them as 'lazy and hopeless people' (Wu and Shi, 2005). A RC worker in Guangzhou emphasised that increasing benefits for MLSS claimants would create welfare dependency and place additional financial burden on the government (Wong and $\mathrm{Li}^{2}, 2013$ ).

More importantly, many SOs are underfunded and welfare workers are unable to manage a large number of MLSS cases. According to Xunyang Civil Affairs Bureau (2008), welfare staff at its public assistance centres had to manage different types of social services without sufficient human resources and communication and transport facilities. Another local government explained that there were three major problems constraining its social security services, including a weak service delivery network, insufficient number of public assistance units and inadequate budgets to cover administrative costs (Organisation Department of Shanxi Provincial Committee of the Communist Party, 2012). Clearly, local welfare officials are struggling to fulfil basic social security duties; the implementation of workfare programmes in some regions is actually beyond their capacities. In particular, public assistance in China is mainly financed by contributions from different levels of local governments and some of them have inadequate resources. It was reported that the amount of debt for all village authorities in China in 2004 was between $¥ 600$ billion and $¥ 1,000$ billion (Zhu et al, 2006). 
Some may argue that the Guangzhou municipal government has already used professional social workers to deliver services. There were more than 550 social workers who provided services at 54 comprehensive family services centres in 2012 (China Social Workers Association, 2012).We should recognise the efforts of the Guangzhou government in offering more professional social services to disadvantaged groups. In particular, it aimed to establish a comprehensive family services centre in every administrative area of a SO (Chen, 2013). However, the contributions of social workers to social security provision in China should not be over-exaggerated at this stage. Firstly, there is no administrative guideline or legislation that requires social workers to administrate public assistance. The existing official documents only assign SOs and RCs to manage MLSS applications. Therefore, the involvement of social workers in administrating public assistance is limited and selective. Some SOs and RCs may ask social workers to visit MLSS families and give them welfare advice (China Net, 2011; People Street Family Services Centre, 2012; Dongguan City Tongde Social Work Service Centre, 2013). However, they do not have a statutory duty to deliver core public assistance services.

In summary, key social security workers in China are mainly volunteers or untrained bureaucrats. Most of them do not receive sufficient training to accurately assess the needs of unemployed claimants, nor do they have the required knowledge to design effective programmes to tackle welfare recipients' employment barriers. They are also overburdened, lacking sufficient resources to deliver basic services. The deficiencies of China's social 
security administration have allowed some volunteers and welfare officers to abuse power by forcing unemployed recipients to do community work regardless of their caring duties and health conditions.

\section{Welfare sanctions and appeals}

In China, welfare workers from RCs and SOs can easily terminate or reduce the benefits of the MLSS recipients without going through a stringent procedure. For example, a disabled MLSS applicant in Guangzhou was disappointed with a staff member of an RC who had refused to give him a full unemployment payment. The staff member claimed that the disabled claimant's wife had work ability so that only 'low income' benefit could be granted. Moreover, the applicant was asked to state in the application form that his wife's monthly salary was $¥ 500$, even though she actually did not work (Ngok, 2012). Another applicant said that a RC deducted her benefit by $¥ 50$ because her neighbours informed them that she received unreported income by selling goods on the street (Ngok, 2012). Obviously, workers of the RC in Guangzhou have a great deal of power to decide the amount of payment and terminate benefits without having any rigorous procedure. Some towns and villages in China can terminate the benefits of MLSS recipients according to the decisions of a committee composed of representatives of a village. For example, Xikou Town ceased the benefits of 100 families following the meetings of its village evaluation committee (Chengdu Commercial Post Net, 2011). 
Some local governments will occasionally ask several departments to take a joint action against welfare fraud. For example, several government departments in Henan province jointly checked public assistance applications approved by lower-level administrative units. As a result of this exercise, the local authority terminated the benefits of more than 435,000 recipients in five counties (Beijing Morning Post, 2011). The issue of concern is whether frontline bureaucrats who implement large scale anti-fraud campaigns have seriously taken the circumstances of welfare recipients into account. It was reported that some recipients' benefits were terminated without receiving prior notice. The affected recipients were unable to get a clear explanation from the authorities on the reasons for terminating their benefits (Beijing Morning Post, 2011; Chinese Commercial Post, 2012; People’s Daily Net, 2012).

More importantly, many local authorities have restricted the welfare rights of poor people by adding extra benefit criteria. In Guangzhou, the benefit of a MLSS recipient was ceased because he owned a rice cooker (Ngok, 2012). A welfare worker in another study said: 'we will not approve MLSS applications for those who have a big house and many electrical appliances and a car' (Wong and Li, 2013). A similar policy has been adopted by other local authorities. For example, according to the Instruction of the Minimum Standard of Living Scheme in Shandong province, recipients' benefits will be terminated if they are found having meals at luxurious restaurants, possessing items such as mobile phones, digital cameras or a refrigerator. Their benefits also will be terminated if they have some unacceptable behaviour such as taking illicit drugs, paying for sex and violating national birth control policy (Wu and Shi, 2005). 
Although China's laws allow welfare claimants to use administrative appeals to take abusive welfare officials to court, it is difficult to exercise this right in reality. The Urban Residents' Minimum Living Standard Scheme Ordinance in 1999 states that if an unemployed claimant does not agree with a welfare worker's decision on benefit cuts, he/she can ask the Civil Affairs Bureau to re-examine his case through an 'administrative review'. If he/she is not satisfied with the outcome of the administrative review, he/she can take the concerned government department to the court through 'administrative litigation'. A further appeal can also be lodged if he/she is not satisfied with the court's sentence.

In fact, it is almost impossible for poor people in China to defend their welfare rights. Zhang (2009) drew our attention to several problems with the existing administrative review system. Firstly, China's law does not require all administrative review officers to have the same qualifications. This means that the officers might not have adequate knowledge to perform a high standard of review. Secondly, the status of administrative review officers is relatively low; they are not entitled to specific job-related benefits enjoyed by other civil servants. However, they have to take a heavy workload. Thus, it is difficult to attract high quality university graduates to do the job. Thirdly, many local authorities do not provide sufficient financial support for their administrative review units. As a result, the officers are overloaded and do not have sufficient time and essential assistance to review all cases.

In addition, many government departments adopt a non-cooperative attitude by delaying or 
even rejecting review officers' requests for essential documents (Xie, 2010). Some even reject the results of the administrative reviews. In short, the administrative review units are too weak to enforce their decisions.

Welfare claimants in China also can hardly lodge complaints through administrative litigations. In the first place, not all appeals will be accepted by the courts. In particular, sensitive cases can be rejected on the basis of political reasons (O'Brien and Li, 2004). More importantly, a Chinese court can seldom carry out a fair trial because the appointment of judges and the allocation of the court's budget are controlled by senior officials of the local governments (O’Brien and Li, 2004).

The status of judges in China is relatively low and the power of the court is very weak. Very often, the decisions of a court are influenced by senior local officials and the Chinese Communist Party's cadets, as well as representatives of the People's Congress (Ma, 2011). In Liu's words (2006: 94), 'local political legitimacy substantially shapes the operation of legal procedures in the judicial process'. Zhang (2003) even claimed that a judge in China is 'little more than a bureaucratic clerk', as sentences of a court are mainly decided by senior officials within 'the power pyramid' (cited in Liu, 2006: 94). It is obvious that China's judiciary is not independent of central and local administration and welfare appellants can hardly use it to defend their rights.

Expensive legal costs are another obstacle preventing welfare claimants from seeking justice. 
After investigating the administrative litigations in rural China, O’Brien and Li (2004: 78) pointed out: 'Litigating is expensive; getting a case accepted is difficult and long delays are common'. Villagers also claimed that 'it is futile or even dangerous to contest unfair administrative decisions or unjust sanctions' (Hung, cited in O'Brien and Li, 2004: 76). Also, welfare appellants are difficult to receive legal aid that is administrated on a regional basis. The application criteria of legal aid are decided by local authorities based on their financial conditions (Zhang, 2011). This arrangement has led to variations among local authorities, creating legal aid inequality in China. To qualify for legal aid assistance, welfare recipients must give income evidence. This means that unemployed recipients from rural areas have to ask a VC which imposed welfare sanctions on them to issue income certificates. However, their VCs may refuse to give them the certificates to challenge their own administrative decisions. Xiamen Zhang (2011), a lawyer from a regional law centre, reported that a VC did not issue an income certificate to a legal aid applicant and this type of malpractice has never been challenged in her region.

Liu and Chen (2008), senior government legal officials in Sichuan province, pointed out other problems of the existing legal aid system. Firstly, many local governments' legal aid budgets are small; each year there is less than a quarter of 700,000 eligible applications can receive legal aid. Secondly, some local authorities put additional criteria so that many poor people have been excluded from receiving legal support. Thirdly, some law firms are unwilling to take up legal aid cases because some local authorities refuse to pay them travel and accommodation expenses. Fourthly, there is inequality in legal aid services between rural 
and urban areas. Many county governments have not allocated sufficient resources, excluding poor rural residents from accessing legal assistance. In short, there is no effective administrative and legal advocacy mechanism in China for checking the behaviour and ultimately accountability of welfare bureaucrats.

\section{Conclusion}

This paper uses Guangzhou and some examples in other regions to illustrate the impact of workfare in China. It was found that the rights of the MLSS recipients have been suppressed by volunteers of the RCs and workers of the SOs as most of them do not possess relevant welfare qualifications. As illustrated previously, unemployed recipients in Guangzhou did not receive adequate workfare information and were forced to take jobs regardless of their caring duties and health conditions. The deficiencies of volunteers in providing public services were also reported in Western welfare states. For example, volunteers were accused of having high levels of absenteeism and turnover, being unreliable, and having poor commitment to work (Brudney, 1993). After interviewing 21 senior managers of public libraries, Nesbit and her colleagues (2012:11) reported that volunteers were difficult to be recruited in some disadvantaged communities and some tasks could not be easily transferred to volunteers because 'potential confidentiality issues, safety concerns, or interactions with vulnerable populations'.

Given the limitations of volunteers to provide public services, more and more countries are 
using professional welfare workers to manage social security. It was found that social workers in some developed countries play a dual role in providing benefits and offering counselling services to social security recipients (Eardley et al, 1996). According to the International Federation of Social Workers (2004), social workers are expected to serve their service users in accordance with social work values such as compassion, empathy, caring, and challenging unjust policies and practices.

It should be stressed that welfare workers are faced with 'increasing pressures to both enforce eligibility and compliance standards' following the implementation of workfare (Handler, 2005). In Australia, workfare regulations and the rationalities of new public management have constrained social workers' autonomy. Despite these challenges, social workers equipped with professional ethics still found some space 'to-frame the participation agenda so that it seems congruent with the formal, theoretical and substantive rationalities of social work' (McDonald \& Chenoweth, 2009: 157). Based on the experiences of the USA, Handler (2005) proposed that 'workfare offices must be separated from the benefit offices'. This implies that social workers should use their skills to support unemployed workers instead of monitoring their behaviour and imposing sanctions. In short, welfare workers equipped with professional ethics tend to defend the welfare rights of poor citizens in the process of implementing workfare. The use of professional social workers instead of volunteers is the direction China's public assistance policy should obviously go.

As discussed in the earlier part of this paper, welfare claimants in Western democratic 
societies can lodge complaints through administrative reviews and also defend their rights through an independent judiciary. On the other hand, China is an authoritarian polity in which most power is in the hands of government officials. The judiciary actually relies heavily on local government officials for paying the salaries of judges, clerical staff and the expenses of office facilities. More importantly, the appointments of judges are made by senior government officials. As a result, the court's decisions have been deeply influenced by higher-ranking administrative units and various political actors instead of a judge's own judgement. Thus, China's legal system can hardly effectively defend the rights of disadvantaged groups, nor stop the abuses of the welfare officers.

The case of China has shown that the nature of Western workfare is actually a product of democratic countries in which the administrative review mechanism and the judicial system can more effectively check the behaviour and decisions of welfare officials. Therefore, coercive measures associated with workfare are more acceptable to the general public, who believe that welfare sanctions can be an effective means to tackle welfare dependency. In undemocratic welfare states, however, welfare officers' power will not be contested by a bureaucrat-controlled judiciary that serves mainly the interests of government officials. Under this political system, workfare measures have directly extended the power of social security officers to control poor people and workfare becomes an oppressive and abusive means to push more unemployed recipients to the labour market, regardless of their circumstances, or forces them to seek support from family or accept any available job. The consequences of workfare in an undemocratic polity like China likely excludes unemployed recipients from 
state benefits, helping preserve its minimal public assistance scheme.

\section{Note:}

1. Ngok's data was collected from a longitude study between April 2009 and April 2011. Respondents of the study included 46 recipients of the MLSS and 4 low income households from 11Residents'Committees under the jurisdiction of one Street Office in Guangzhou. Each respondent was interviewed every six months and a total of five interviews were conducted during the study period.

2. Wong and Li's study was conducted in two districts of Guangzhou from March to May 2011. Respondents of the study included five government officials, 17 frontline workers and 24 MLSS claimants. 


\section{References}

Beijing Morning Post (2011) 'Henan’s Government Departments Jointly Checked MLSS

Fraud; 425,000 Recipients' Benefits Were Terminated', 5 September.

http://news.xinmin.cn/domestic/gnkb/2011/09/05/11949656.html.

Brudney, J.L. (1993) "Volunteer Involvement in the Delivery of Public Services: Advantages and Disadvantages”, Public Productivity \& Management Review 16(3): 283-297.

Cai, Y. (2002) 'The Resistance of Chinese Laid-Off Workers in the Reform Period', The China Quarterly 170: 327-44.

Centrelink (2012) Reviews and Appeals.

http://www.centrelink.gov.au/internet/internet.nsf/legal/review_appeal.htm.

Chen, F. (2000) 'Subsistence Crises, Managerial Corruption and Labour Protests in China', The China Journal 44: 41-63.

Chen, J.H. (2013) Guangzhou Municipal Government Report 2013.

$\underline{\text { http://210.26.5.6:81/index/dqbg/showdoc.asp?blockcode=DQBGGZGZ\&filename=201 }}$ $\underline{302192030 .}$

Chengdou Commercial Post Net (2011) 'Guangan City Adopts Democratic Means to Terminate the Benefits of MLSS Recipients', 4 November. http://e.chengdu.cn/html/2011-11/04/content_274575.htm.

China Net (2011) The Main Duties of Social Workers at the Hong Mian Comprehensive Services Centre in Shi Long are to Serve Older People, Disabled People and MLSS 
Families. http://www.jianghuaisw.com/bbs/viewthread.php?tid=122838.

China Social Workers Association (2012) Guagzhou Will Establish 140 Family Services Centres before Mid-2012.

http://www.cncasw.org/sgsw/sqsg/201203/t20120326_11527.htm.

Chinese Commercial Post (2012) ‘A Citizen Was Confused about Benefit Termination', 15 January. http://news.hsw.cn/system/2012/01/15/051215929.shtml.

Co-author (2012).

Co-author and others (2011).

Directgov (2012) 'How to Appeal Against a Benefits Decision'.

http://www.direct.gov.uk/en/MoneyTaxAndBenefits/BenefitsTaxCreditsAndOtherSupp ort/BeginnersGuideToBenefits/DG_10013949.

Dongguan City Tong De Social Work Service Centre (2013) Social Workers Visit MLSS

Families. http://dgtongde.com/tongde/webfile/NewsView.asp?ID=567\&SortID=41.

Eardley, T., Bradshaw, J., Ditch, J., Gough, I. and Whiteford, P. (1996) Social Assistance in OECD Countries. London: HMSO.

Ellis, K. (2007) 'Direct Payments and Social Work Practice: The Significance of 'Street-Level Bureaucracy' in Determining Eligibility', British Journal of Social Work 37(3): 405-422.

Esping-Andersen, G. (1990). The Three Worlds of Welfare Capitalism. Princeton, N.J: Princeton University Press.

Free Legal Advice Centres (2012) Time to Reform Social Welfare Appeals System. http://www.flac.ie/news/2012/10/24/time-to-reform-social-welfare-appeals-system/.

Geetter, E. (1988) ‘Attorney's Fees for Section 1983 Claims in Fair Hearings: Rethinking 
Current Jurisprudence', The University of Chicago Law Review 55(4): 1267-1301.

Golin, E. (1995) 'Solving the Problem of Gender and Racial Bias in Administrative Adjudication', Columbia Law Review 95(6): 1532-1567.

Handler, J.F. (2005) "Workfare Work: The Impact of Workfare on the Worker/Client Relationship", Social Work and Society International Online Journal 3(2). http://www.socwork.net/sws/article/view/192/479.

House of Commons (2009) Jobcentre Plus: Qualifications, 20 July. http://www.publications.parliament.uk/pa/cm200809/cmhansrd/cm090720/text/90720w $\underline{0030 . h t m .}$

Howard, C. (2012) 'The Contradictions of Individualized Activation Policy: Explaining the Rise and Demise of One To One Service in Australia', Critical Social Policy 32 (4): 655-676.

Huang Hua Gang Street Community Service Centre (2013) Service Guide for Huang Hua Gang Street's Community Service Centre. http://gz.bendibao.com/cyfw/201047/fw39436.shtml.

International Federation of Social Workers (2004) Ethics in Social Work, Statement of Principles. http://ifsw.org/policies/statement-of-ethical-principles/.

Kornbluh, F. (1998) 'The Goals of the National Welfare Rights Movement', Feminist Studies, 24(1): 65-78.

Lens, V. (2007) 'In the Fair Hearing Room: Resistance and Confrontation in the Welfare Bureaucracy', Law \& Social Inquiry 32(2): 309-332.

Lens, V. (2011) 'Contesting the Bureaucracy: Examining Administrative Appeals', Social and 
Legal Studies 20(4): 421-439.

Lipsky, M. (1980) Street-Level Bureaucracy: Dilemmas of the Individual in Public Services. New York: Russell Sage Foundation.

Liu, P. and Chen, L. (2008) Legal Aid: Importance, Barriers and Solutions.

http://www.chinalawedu.com/news/16900/178/2008/10/ji02052622115201800214326$\underline{0 . h t m}$.

Liu, S. (2006) 'Beyond Global Convergence: Conflicts of Legitimacy in a Chinese Lower Court', Law and Social Inquiry 30(1): 75-106.

Lodemel, I. and Trickey, H. (2000) 'A New Contract for Social Assistance', in I. Lodemel and H. Trickey (eds.) An Offer You Can't Refuse: Workfare in International Perspective, pp. 1-40. Bristol: The Policy Press.

Ma, H. (2011) 'Problems and Suggestions of Amendments of the Administrative Procedure Law', Legal Forum, 5.

McDonald, C. and Chenoweth, L. (2009) “(Re) Shaping Social Work: An Australian Case Study", British Journal of Social Work 39: 114-160.

Ministry of Civil Affairs (2008) Civil Affairs for 30 Years: 1978-2008. Beijing: Chinese Society Press.

Ministry of Civil Affairs (2010) China Civil Affairs'Statistical Yearbook. Beijing: China Statistics Press.

Ministry of Justice (2011) Annual Tribunals Statistics 2010-11: 1 April 2010 to 31 March 2011. http://www.justice.gov.uk/downloads/statistics/tribs-stats/annual-tribunals-statistics-201 
0-11.pdf.

Nesbit, R., Brudney, J. and Christensen, R. (2012) Exploring the Limits of Volunteerism in Public Service Delivery: Substituting Volunteer Labor for Paid Labor. New York: City University of New York.

Ngok, K. (2012) A Longitude Study of Public Assistant Recipients in Guangzhou. Guangzhou: Sun Yat-Sen University. (An Unpublished Research Study).

Organisation Department of Shanxi Provincial Committee of the Communist Party (2012) Report on Social Assistance Policy. http://www.sxdygbjy.com/html/165/167/167-75312.html.

People Street Family Services Centre (2012) Centre Introduction. http://www.96909.gd.cn/sqfww/showjiatingxiangxi.asp?f_number=0108.

People's Daily Net (2007) Thinking about Rural Social Stability in Rural Areas in A New Era, 22 April. http://nc.people.com.cn/GB/5648179.html.

People’s Daily Net (2012) Why was My MLSS Benefit Terminated? 30 April. http://liuyan.people.com.cn/redirect.php?fid=594\&tid=1436111\&goto=nextoldset.

Qingdao Public Administration Institute Research Team (2003) A Study of China's Community Administration Model and Its Implementation - The Case of Qingdao. http://www.mca.gov.cn/mca/news/2003luntan/lunwen14.html.

Qiu, L.L. (2005) Restrictions and Suggestions on the Development of Urban Minimum Standard of Living Scheme. Statistical Research, 12: 5-16.

Reich, C. A. (1965) 'Individual Rights and Social Welfare: The Emerging Legal Issues', Yale Law Journal 74: 1244-1257. 
Seale, E., Buck, A. and Parrotta, K. (2012) 'Who's to Blame? The Identity Talk of

Welfare-To-Work Program Managers', Sociological Perspectives 55(3): 501-527.

Sargent Shriver National Center on Poverty Law (2014) 'Combating Biased Adjudication in Claims for Social Security Disability Benefits'. http://www.povertylaw.org/communication/advocacy-stories/sicilia.

State Council (2007) State Office's Notification for Establishing a Nationwide Minimum Standard of Living Scheme in Rural Areas. Beijing: State Council.

Tang, J. (2002) Establish a Comprehensive Minimum Living Security System. Beijing: Chinese Academy of Social Science. http://www.cass.net.cn/chinese/s09_shx/zlk/39.htm.

Tang, J. (2005) The Minimum Standard of Living Scheme in Cities and Countryside. Beijing:

The Institute of Sociology of the Chinese Academy of Social Sciences. http://203.93.24.66/shxw/shzc/P020050824304842967803.pdf.

The Princess Royal Trust for Carers (2009) A study into the use of personalised services, notably Direct Payments, to benefit carers living in rurally isolated areas. Glasgow: The Princess Royal Trust for Carers.

The Telegraph (2013) 'China's Mega City: The Country's Existing Mega Cities’, 30 September.http://www.telegraph.co.uk/news/worldnews/asia/china/8278325/Chinas-me ga-city-the-countrys-existing-mega-cities.html.

Vendel, J. (2005). 'General Bias and Administrative Law Judges: Is There a Remedy for Social Security Disability Claimants?' Cornell Law Review 90 (3): 769-809.

Wang, Y. (2010) 'Building a Shared-Development Oriented Social Security System', in J. Chan and Y. Wang (eds.) China Social Security System Development Report. Beijing: 
Social Sciences Academic Press.

Wong, L. and Li, Q. (2013) 'The Determinants of Implementing China's Dibao Scheme :

From the Perspective Of Street-Level Bureaucracy', in K. Ngok and W. Guo (eds.)

Chinese Public Policy Review, 6. Shanghai: Shi Ji Ge Zhi.

Wu, L. and Shi, G. Q. (2005) 'Ethics and Flaws on China’s Minimum Living Security

Scheme', Journal of Nanjing Normal University 2: 20-25.

Xian Street Office (2013) Xian Street Office's Administration and Legal Documents

Summary, 31 May.

http://xiancun.thnet.gov.cn/v2011/zwgk/gkml/201305/t20130531_666705.html.

Xie, Y. (2010) Improvement and Innovation on the Administrative Review System.

http://fzj.xinmi.gov.cn/sitegroup/168010/html/ff80808116b206320116cd142

14a02cd/2010082017382808.html.

Xin Hua Net (2007) 'One Stop for 26 Social Assistance Services’, 14 September.

http://gd.xinhuanet.com/dishi/2007-09/14/content_11153722.htm.

Xinhua Net (2006) 'Because of the Minimum Wage is Too Low, Some People Prefer to Live

On Public Assistance Rather Than To Work', 9 April. http://news.xinhuanet.

com/mrdx/2006-04/09/content_4401914.htm.

Xunyang Civil Affairs Bureau (2008) Report on the Minimum Standard of Living Scheme in Urban and Rural Areas of Xunyang. http://www.jxjzw.gov.cn/JJXY/

ShowPublic.aspx ?TableName=Status\&typeName=\%B9\%A4\%D7\%F7\%B6\%AF\%CC $\%$ AC\&Flag=Status $\& I D=136$.

Yunnan Net (2012) 'MLSS Benefits Terminated if Failing to Do Community Work', 24 April. 
http://honghe.yunnan.cn/html/2012-04/24/content_2163347.htm.

Zhang, J. (2009) An Analysis on the Related Issues of the Administrative Reconsideration. http://www.gxgg.gov.cn/news/2009-04/3923.htm.

Zhang, S. F. and Tang, J. (2005) The Level of Minimum Standard of Living Scheme Just Only Enough for Food and Clothes. Beijing: Institute of Sociology of the Chinese Academy of Social Sciences. http://203.93.24.66/shxw/shzc/P020050908295415620463.

Zhang, X. M. (2011) An Examination on Issues about Means Testing for Applicants for Legal Aid. http://www.jsflyz.gov.cn/yjtt/fyzllyj/201112/t20111221_45412.htm.

Zhu, G., Tan, Q. and Zhang, J. (2006) Township and Village Debts. Beijing: Social Sciences Academic Press. 